\title{
Applying heat pumps to utilize municipal solid waste at St. Petersburg TPP
}

\author{
Milana Treshcheva ${ }^{1}$, Dmitriy Treshchev $^{1}$, and Daria Pozdeeva ${ }^{1, *}$ \\ ${ }^{1}$ Peter the Great St. Petersburg Polytechnic University, St. Petersburg, Russian Federation
}

\begin{abstract}
In this article, we address an urgent problem of solid waste management. We consider the possibility of applying gasification technology for municipal solid waste disposal at existing TPPs in St. Petersburg in order to produce thermal and electric energy. St. Petersburg Northern TPP-21, facing the problem of undercooling of the circulating water in the cooling towers, is proposed as a possible placement site. Using this water as a source of low-grade heat of a heat pump installation is considered as the possible solution to the problem. The study was carried out by calculating the thermal circuits in the Boiler Designer program, and calculating the heat pump in the Cool Pack program. The efficiency of the installation is achieved by increasing the supply of thermal energy and increasing the environmental friendliness of the installation by reducing thermal pollution. We have also calculated the limits of cost-effective heat pump application.
\end{abstract}

\section{Introduction}

According to the Federal State Statistics Service, in 2005, about 3 billion tons of waste was recorded on the territory of the Russian Federation, in 2015 the figure reached 5.06 billion tons, reaching $69 \%$ increase of waste in 10 years.

The average volume of waste disposal in our country is only $35 \%$, which leads not only to an increase in the volume of accumulated waste, but also to a loss of up to $90 \%$ of useful products that are in demand on the market.

Currently, 1.7 million tons of municipal solid waste (MSW) per year is generated as a result of the activities of the population, organizations and enterprises in St. Petersburg. Only a small part of the solid waste generated in St. Petersburg is processed at two specialized waste recycling plants (WRP), while the bulk of the solid waste is disposed at landfills without processing.

One of the ways to reduce the damage to the environment of St. Petersburg may be the disposal of waste by producing secondary fuel for thermal and electric energy production at urban TPPs.

The following fractions of solid waste with a relatively high heat of combustion are used for the production of alternative fuel (AF) based on solid waste: paper, textile, wood, plastic [1].

The production process includes several stages: separation, preliminary grinding (can be done before separation), grinding (crushing) to the desired fraction size and drying of the raw material. After drying, alternative fuel can be used, but more often high-pressure fuel briquettes are manufactured by mechanical presses as the final step of the process. The average calorific value of RDF fuel is within the range from 12 to $18 \mathrm{MJ} / \mathrm{kg}$. The approximate morphological composition of solid waste generated in St. Petersburg is shown in Table 1 [2-6].

Table 1. Morphological composition of municipal solid waste in St. Petersburg

\begin{tabular}{|c|c|c|c|}
\hline $\begin{array}{c}\text { Type of } \\
\text { waste }\end{array}$ & $\begin{array}{c}\text { Relative } \\
\text { share in total } \\
\text { composition, \% }\end{array}$ & $\begin{array}{c}\text { Type of } \\
\text { waste }\end{array}$ & $\begin{array}{c}\text { Relative } \\
\text { share in total } \\
\text { composition, \% }\end{array}$ \\
\hline $\begin{array}{c}\text { Organic } \\
\text { waste }\end{array}$ & 27.4 & Glass & 8.9 \\
\hline Polyethylene & 7.4 & Wood & 2.5 \\
\hline $\begin{array}{c}\text { Paper and } \\
\text { cardboard }\end{array}$ & 21.5 & PVC & 0.1 \\
\hline $\begin{array}{c}\text { Other } \\
\text { plastics }\end{array}$ & 2.5 & PAT & 3.4 \\
\hline $\begin{array}{c}\text { Non-ferrous } \\
\text { metals }\end{array}$ & 3.8 & $\begin{array}{c}\text { Inert } \\
\text { materials }\end{array}$ & 12.8 \\
\hline $\begin{array}{c}\text { Textile, } \\
\text { leather, } \\
\text { rubber }\end{array}$ & 4.3 & $\begin{array}{c}\text { High } \\
\text { pressure } \\
\text { plastic }\end{array}$ & 1.0 \\
\hline $\begin{array}{c}\text { Ferrous } \\
\text { metals }\end{array}$ & 0.8 & $\begin{array}{c}\text { Other } \\
\text { materials }\end{array}$ & 2.8 \\
\hline \multicolumn{2}{|c|}{} & Total & 100.0 \\
\hline
\end{tabular}

From the morphological composition of the solid waste arriving for sorting, it is possible to determine the percentage of AF extraction, which is the sum of the percent of materials with a relatively high calorific value included in the AF. In this case, for St. Petersburg, the recovery percentage is approximately $30 \%$.

According to the territorial scheme of waste management in St. Petersburg, the city is divided into two

\footnotetext{
* Corresponding author: daripozdeeva@ya.ru
} 
zones of regional operators - northern and southern. According to this scheme, in 2015, in the coverage area of regional operator No. 1 (southern), 845898.78 tons of solid waste were generated, and in the coverage area of operator No. 2 (northern) - 857454.37 tons. [7]

Thus, in St. Petersburg, the centers for processing solid waste can be located in the northern and southern parts of the city dividing the volume of all generated solid waste in two halves. Taking for calculation the volume of solid waste generated in 2015 , with a share of $30 \%$, the annual output of AF will be $253769.6 \mathrm{t} /$ year in the southern and $257236.3 \mathrm{t}$ / year in the northern part of the city with a minimum calorific value of $12 \mathrm{MJ} / \mathrm{kg}$.

Direct combustion of AF requires installation of expensive gas cleaning equipment. In addition, the caloric content of AF is variable, since it depends on the composition of the sorted solid waste. As a solution, it is possible to use the most promising method of thermal utilization - solid waste gasification with obtaining synthesis gas during gasification and its further use as a fuel in the steam-power cycle. Using this technology eliminates the direct burning of waste, and the calorific value of the synthesis gas is constant. [8-10].

Similar technology is used in the city of Lahti (Finland). The local TPP is the largest waste gasification station in the world. 250 thousand tons / year of sorted solid waste is burnt at the plant. The process of synthesis gas production from sorted WRP takes place in a gasifier with circulating fluidized bed (CFB), where the AF enters the system. [11-15].

The annual fund of working hours of the TPP, taking into account the shutdowns for repairs according to the current regulatory documentation, will be 8232 hours / year. Thus, fuel consumption RDF with calorific value 12 $\mathrm{MJ} / \mathrm{kg}$ will be $8.68 \mathrm{~kg} / \mathrm{s}$. The efficiency of gasifiers of modern manufacturers averages $87.5 \%$, and the average efficiency of modern steam boilers of domestic manufacturers operating on synthesis gas is $93 \%$, then the thermal capacity of the steam boiler will be $84.76 \mathrm{MW}$. The steam consumption of standard unified parameters (pressure $14 \mathrm{MPa}$, temperature $540{ }^{\circ} \mathrm{C}$ ) at the outlet from such a boiler will be approximately $120 \mathrm{t} / \mathrm{h}$.

NorthernTPP-21 in St. Petersburg was proposed as a possible site for generated solid waste disposal as it meets the following criteria:

- located in an area with satisfactory transport and logistic accessibility, at a significant distance from residential areas;

- meets the legal requirements for compliance with the regulatory sanitary protection zone (SPZ) for waste processing and incineration enterprises with a capacity of more than 40 thousand tons of solid waste per year $-1000 \mathrm{~m}$ according to SanPiN 2.2.1/2.1.1.1200-03;

- has free required size sites to accommodate both the new generation source and the solid waste sorting zone;

- there are significant connected thermal loads.

Northern TPP-21 consists of 5 blocks T-100 / 120130. When all five turbines are operating in pure condensation mode, the total nominal flow rate of cooling water will be $71000 \mathrm{~m}^{3} / \mathrm{h}$. The technical water supply system (TWSS) at the TPP-21 is reverse with cooling towers. Design total capacity of cooling towers in water is $24000 \mathrm{~m}^{3} / \mathrm{h}$.

Currently, there are restrictions on the supply of electric power due to the lack of performance of the existing fuel assembly system at the Northern TPP-21 in summer. The reason for the limitations of available power is the undercooling of the circulation water in the cooling towers, as well as the inability of the circulation pumps to provide the required water supply. The average annual temperature of the circulating water at the outlet of the cooling towers of the TPP-21 is $30{ }^{\circ} \mathrm{C}$, in summer the temperature can rise to $40^{\circ} \mathrm{C}$.

Currently, one of the most promising, environmentally friendly, resource- and energy-saving technologies is heat pump technology. The use of heat pumps allows not only to use the secondary fuel and energy resources (SER) generated at the heat station and to improve environmental performance, but also to increase the economic efficiency. Schematic solutions for the use of heat pump units at thermal power plants have been developed and investigated.

One of the ways to include a heat pump installation in the thermal circuit of a TPP is to introduce it into the condenser cooling system of a steam turbine installation. The advantage of implementing such a circuit solution is not only due to the significant amount of low-grade heat released in the condenser cooling system, but also due to sufficiently high temperature level, high consumption, absence of impurities, low chemical activity and slight fluctuations in the temperature and pressure of process water.

When using circulating water at the outlet of the cooling towers of TPP-21 as a source of low potential heat of the heat pump installation, it is possible to solve the problem of its undercooling, as well as to increase the efficiency of the TPP work at AF.

The purpose of the work is to analyze the possibility of increasing the environmental, economic and energy efficiency of thermal power plants on AF by installing a heat pump.

\section{Methods}

In the Russian energy sector, the most common recommendations are to install a heat pump in a circuit for heating the heating system feed. However, with the transition to a closed heat supply scheme, the amount of make-up water will decrease by an order of magnitude, which significantly reduces the efficiency of using a heat pump. The heat obtained by using a heat pump at thermal power plants operating in an open heat supply system can be used to heat the return network water of the heating system. The heat pump in this case is installed before the network heater for heating the network water. This heat pump installation scheme is widespread. The profit is achieved due to additional heat production from the TPP, while the total electric load of the TPP and the total consumption of the burned fuel remain unchanged. 
The study was conducted by modeling and further calculating thermal circuits in the licensed program Boiler Designer, developed by OPTSIM-K, as well as calculating the heat pump using the Cool Pack program.
A possible thermal scheme of a TPP on AF using a heat pump unit (HPU) is shown in Figure 1.

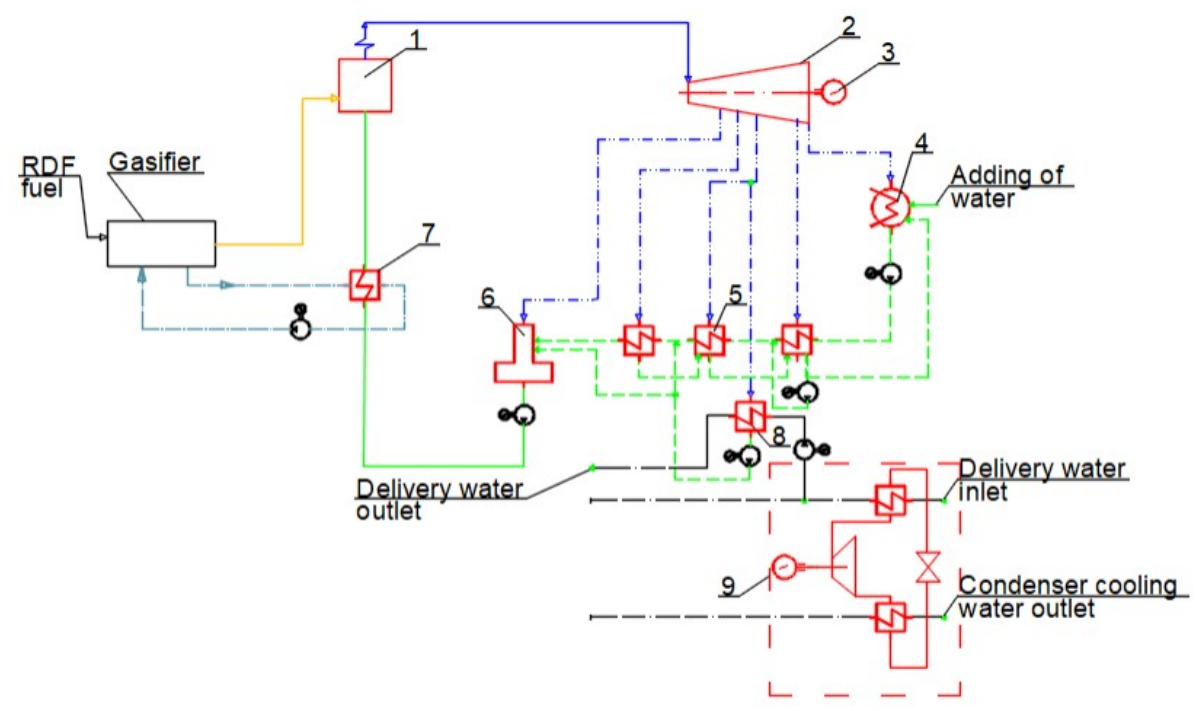

Fig. 1 Schematic diagram of thermal power plant at AF.

Fresh steam to the turbine (2) comes from a steam energy boiler (1) operating on synthesis gas. The power on the turbine shaft is converted into the electric power of the generator (3), which is supplied to external consumers.

The steam spent in the turbine enters the condenser (4), where it is completely condensed and then by the condensate pumps, through the system of regenerative turbine heaters (three low pressure heaters) (5), the turbine condensate is fed to the feed deaerator (6). Deaerated feed water from the deaerator tank is supplied to a steam energy boiler by feed pumps, through a waterwater synthesis gas cooler (performs the function of a high-pressure heater) (7).

Steam from the cogeneration selection of the turbine enters the network water heaters (PSV type) (8), where it heats the water for the purpose of heat supply to external consumers.

This scheme differs from the traditional steam-power circuit with a heating turbine (2) as the part of HPH (high pressure heater) of the turbine is replaced by a water-towater heat exchanger and the presence of a heat pump. (9).

In this study we made the following assumptions. The temperature of the low-grade heat source is accepted as the average annual temperature. Freon R134a, which is considered to be completely ozone-safe, has been adopted as a working fluid. The heat released in the condenser of the heat pump is $5 \mathrm{MW}$ (a low-power heat pump is considered). The temperature differences at the outlet of the evaporator and condenser taken for calculations are equal to $5{ }^{\circ} \mathrm{C}$ and $2{ }^{\circ} \mathrm{C}$, respectively.

For research purposes, the lower threshold of the heat of combustion of the RDF fuel is $12 \mathrm{MJ} / \mathrm{kg}$.

The calculation is made for the least efficient of the existing schemes - the simplest scheme of a vapor compression heat pump installation without a regenerative heat exchanger and subcooler. Evaluation of the energy conversion coefficient of the heat pump in this scheme will allow us to evaluate the effectiveness of the use of the heat pump as a whole.

The temperature of the feed water after HPH at the inlet to the boiler was adopted at $206.5{ }^{\circ} \mathrm{C}$. The temperatures of the forward and reverse network water are taken respectively $95{ }^{\circ} \mathrm{C}$ and $55{ }^{\circ} \mathrm{C}$, while the consumption of network water was $1350 \mathrm{t} / \mathrm{h}$.

\section{Results and Discussion}

Figure 2 shows the cycle of the heat pump during operation under these conditions in the Cool Pack program. 


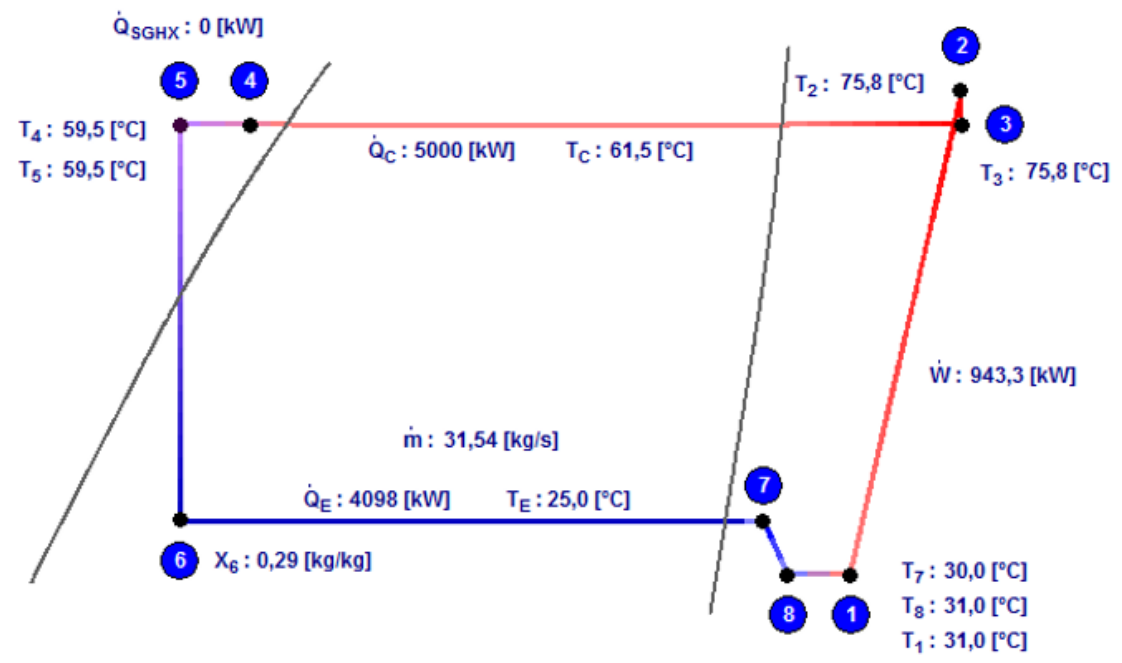

Fig. 2 Heat pump cycle

\begin{tabular}{l|ll|l}
\hline \hline REFRIGERANT : R134a & COP : 4,344 & COP* $^{*} 4,387$ & $\eta_{\text {CARNOT }: 0,537}$
\end{tabular}

Calculations show that the heat pump compressor drive requires $0.943 \mathrm{MW}$ (see Fig. 2). The amount of heat received from the cold source was $\mathrm{Q}=4.1 \mathrm{MW}$. The electricity conversion coefficient, which is the ratio of the heat supplied to the heat consumer to the energy on the compressor drive, in this case was 4.34. The use of installations with a conversion factor of 3-5 is effective. [16-20]

Figure 3 shows the corresponding calculation model, consisting of a gasifier, a steam boiler, a turbine, and auxiliary equipment. The electric power generated in the steam turbine plant was 28.25 MW (see Fig. 3).

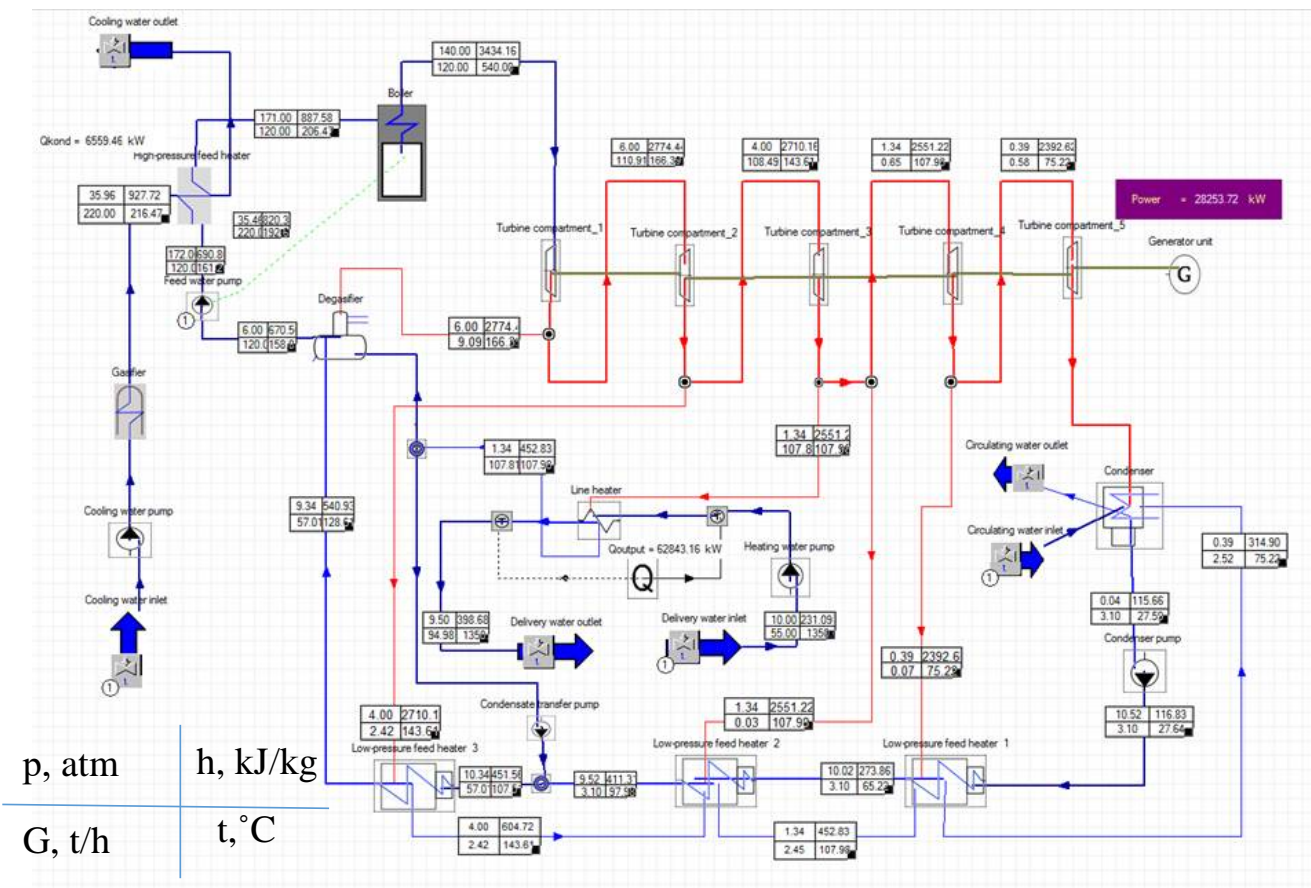

Fig. 3 Boiler installation in Boiler Designer

The main technical indicators obtained on the basis of the calculation models are summarized in table 2. In the Heat pump option electric power consumption for own needs increases by the value of the auxiliary needs of the heat pump compressor drive. The heat consumption for own needs was not taken into account in the calculations. The specific fuel consumption for heat supply is assumed to be constant and equal to $155 \mathrm{~kg} / \mathrm{Gcal}$.
Table 2. Main technical indicators of the calculation models

\begin{tabular}{|l|l|l|l|}
\hline & & Performan \\
Indicator, measuring unit & $\begin{array}{l}\text { Without } \\
\text { HPU }\end{array}$ & $\begin{array}{l}\text { With } \\
\text { HPU } \\
\text { applicatio } \\
\text { of circuits } \\
\text { with HPU } \\
\text { compared } \\
\text { no circuit } \\
\text { without } \\
\text { HPU }\end{array}$ \\
\hline
\end{tabular}




\begin{tabular}{|l|l|l|l|}
\hline Electricity generation, MWh & 236622.00 & 236622.00 & 0.00 \\
\hline Heat supply to consumers, Gcal & 452577.68 & 488588.00 & 36010.32 \\
\hline $\begin{array}{l}\text { Total electricity costs for own } \\
\text { needs at HPU, MWh }\end{array}$ & 0.00 & 7873.44 & 7873.44 \\
\hline Electricity supply, MWh & 236622.00 & 228748.56 & -7873.44 \\
\hline $\begin{array}{l}\text { Total equivalent fuel costs, ton of } \\
\text { standard fuel }\end{array}$ & 107091.71 & 107091.71 & 0.00 \\
\hline $\begin{array}{l}\text { Conditional fuel consumption for } \\
\text { electricity supply, ton of standard } \\
\text { fuel }\end{array}$ & 36942.2 & 31360.58 & -5581.60 \\
\hline $\begin{array}{l}\text { Fuel consumption for heat supply, } \\
\text { ton of standard fuel }\end{array}$ & 70149.5 & 75731.14 & 5581.60 \\
\hline $\begin{array}{l}\text { Specific fuel consumption for } \\
\text { electrical energy supply, g kWh }\end{array}$ & 156.1 & 137.10 & -19.03 \\
\hline $\begin{array}{l}\text { Specific fuel consumption for } \\
\text { heat supply, kg / Gcal: }\end{array}$ & 155.0 & 155.00 & 0.00 \\
\hline Coefficient of fuel utilization & 0.8751 & 0.91 & 0.04 \\
\hline
\end{tabular}

The difference in the supplied electric energy for the year in two versions with equal total costs of equivalent fuel is $\Delta \mathrm{N}=7873.44 \mathrm{MWh}$, in heat energy $-\Delta \mathrm{Q}=$ 36010.32 Gcal. With a market value of one $\mathrm{kWh}$, amounting to 1.234 rubles and an average heat supply tariff of 1007.1 rubles per Gcal, a heat pump installation can be effectively applied on the horizon for 15 years at a cost of $\leq 398.25$ million rubles (without accounting discount rate).

\section{Conclusions}

In this work, we can draw the following main conclusions:

There is a fundamental possibility of using MSW as a fuel for the purpose of energy-efficient production of heat and electric energy at an existing TPP in St. Petersburg. 250 thousand tons / year of sorted solid waste are burnt at the station;

Installing a heat pump allows to increase the energy efficiency by increasing the quantity of thermal energy supply $\Delta \mathrm{Q}=36010.32 \mathrm{Gcal} /$ year and increase the environmental friendliness of the installation by reducing thermal pollution of the environment in the amount of $\Delta \mathrm{Q}=29528.46 \mathrm{Gcal} /$ year. The cost of electrical energy for the compressor drive in this case is $\Delta \mathrm{N}=7873.44$ MWh / year.

In the current economic situation in St. Petersburg it is possible to increase economic efficiency of electric and thermal energy generation at TPP operating on AF through the use of a heat pump circuit with an installation cost of no more than 398.25 million rubles.

\section{References}

1. A. Kalyutik, D. Treshchev, D. Pozdeeva, Recycling municipal solid waste at power-and-heating plants of St. Petersburg, St. Petersburg Polytechnic University Journal of Engineering Science and Technology 25 (3), pp. 59-70, (2019)

2. E. Bernadiner, Yu. Alexandrova, The use of waste as an alternative fuel in a cement kiln, Solid household waste 11, pp. 22-25, (2017)

3. V. Lozhechko, M. Kritsyn. On methods for producing alternative fuel from solid household waste,
Modern Engineering. Science and education 3, pp. 982991, (2013)

4. V.V. Bushikhin, O.N. Kaygorodov, G.M. Polozov, O.E. Fedoseev. Alternative fuels from solid waste. Application and legalization, Ecological Bulletin of Russi, 5, pp. 42-45, (2013)

5. D.A. Cauich-López, L.F. Barrera Payan, Abdelhalim, A.M.N., (...), A.A. Sinitsyn, I.G. Akhmetova, Small-scale steam generation from local solid waste. International Journal of Civil Engineering and Technology 10(2), pp. 2118-2129, (2019)

6. A. Chusov, E. Neguliaeva, M. Romanov, Optimization of the Solid Waste Management System in Saint-Petersburg Based on the Morphological Composition Study, (2018)

7. I.V. Lamzina, A.V. Goldov, Ya. I. Knyazev, I.A. Polozova, V.F. Yellow bellies. Obtaining and using alternative fuels from municipal solid waste for the cement industry, Engineering Herald of the Don 2, 18 (2014)

8. I.G. Stepanchikova, A.V. Derevyanko, V.A. Zaitsev. Secondary fuel from individual components of household waste. Energy: eco mics, tech logy, ecology 2, pp. 40-45, (2014)

9. V.V. Bushikhin, G.P. Colton, A.Yu. Lomtev. RDF from MSW, Municipal solid waste 11, pp. 22-25, (2017)

10. E.L. Shaburov, A.V. Fedyukhin, V.A. Ippolitov, Calculation of the operational parameters of the installation of gasification of solid waste, Scientific and technical statements of SPbPU. Natural and engineering sciences 3, pp. 38-44, (2018)

11. R.Sh. Zagrutdi v, V.N. Negutorov D.G. Malykhin, P.K. Senachin, M.S. Nikishanin, S.A. Filipchenko. Preparation and gasification of municipal solid waste in dual-zone direct process gas generators operating as part of mini-CHP plants and complexes for the production of synthetic liquid fuels, Polzunovsky Bulletin 4/3, pp. 47-62, (2013)

12. M. Bernadiner, M. N. Bernadiner. High temperature waste treatment. Plasma energy sources, Solid household waste 4, pp. 16-19, (2011)

13. Ya. A. Vladimirov, L.V. Zysin. Methodological issues of the energy use of municipal solid waste and gasification products, Scientific and technical statements of SPbPU. Natural and engineering sciences 24, 1, pp. 5-16, (2018)

14. Lennart Ljungblom. Biomass to energy XL, Bioenergy International 63, (2013)

15. I.M. Bernadiner, A.A. Kovalchuk. Utilization of municipal solid waste by air-gasification. Bulletin of Perm National Research Polytechnic University. Applied Ecology. Urban Studies 2, pp. 81-97, (2014)

16. I.D. Anikina, V.V. Sergeyev "Heat pumps' application for energy efficiency rising of steam-power HPP” St. Petersburg St. Polytec. Un. Journal 3(178), pp. 56-61, (2013)

17. I.D. Anikina, V.V. Sergeyev, N.T. Amosov, M.G. Luchko "Heat pumps application in flow-sheet of heat generation at thermal power plants”. Int. Sc. Journal for Altern. Energy and Ecology 3-4 (191-192), pp. 39-49, (2016) 
18. I.D. Anikina, V.V. Sergeyev, N.T. Amosov, M.G. Luchko. Use of heat pumps in turbogenerator hydrogen cooling systems at thermal power plant. Inter. Journal of Hydrogen Energy 42, pp. 636-642, (2017)

19. M.A. Molodkina. Use of heat pump in of turbogenerator air cooling closed circuit system. St. Petersburg St. Polytec. Un. Journal 2(123), pp. 81-85, (2011)

20. 4. M.A. Molodkina "Energy saving in the high power CHP due to the utilization of low-grade heat of cooling tower blowdown” St. Petersburg St. Polytec. Un. Journal 3 (130), pp. 84-88, (2011) 